\title{
Business Representation in the Brazilian Labor Justice from the Corporate Forms Concepts Perspective
}

\author{
Danilo Scramin Alves \\ Faculdade Barão do Rio Branco, Centro Universitário Uninorte, Rio Branco, Brazil \\ Email: daniloscramina@hotmail.com
}

How to cite this paper: Alves, D. S. (2021). Business Representation in the Brazilian Labor Justice from the Corporate Forms Concepts Perspective. Beijing Law Review, $12,27-44$.

https://doi.org/10.4236/blr.2021.121003

Received: December 27, 2020

Accepted: February 17, 2021

Published: February 20, 2021

Copyright $\odot 2021$ by author(s) and Scientific Research Publishing Inc. This work is licensed under the Creative Commons Attribution International License (CC BY 4.0).

http://creativecommons.org/licenses/by/4.0/

\section{cc) (i) Open Access}

\begin{abstract}
This article aims to analyze the forms of representation of the legal entity in Brazilian labor lawsuits, especially in the case of legal representation and the hearing representative, considering the concepts of corporate forms. Based on this discussion, a study was elaborated focused on the presentation of dialogues between indoctrinators, legislation and jurisprudence about the representation of the company in the Brazilian Labor Court, followed by an analysis of these representations from the different meanings of company. The objective of the research is to promote an analysis on how the perception of corporate forms has influenced business representation in the Brazilian Labor Justice. In the end, despite the necessity of further research, it was found that, although both forms of perception are identified in the current system, the Brazilian labor legislature seemed to recognize corporations as real entities for purposes of representation.
\end{abstract}

\section{Keywords}

Business Representation, Brazilian Labor Court, Corporate Forms

\section{Introduction}

Discussions about corporate representation in the Brazilian Labor Courts have increased significantly in recent times, especially due to the changes brought about by the Labor Reform of Law N. 13,467/2017. The rising number of companies in litigation, the constant changes in labor relations in Brazil, the swift perception on business and the outdated base legislation can also be mentioned as reasons for such discussion.

In this sense, it is necessary that new ways of visualizing the structure of com- 
panies and their identity as people are discussed in order to verify the possibilities related to their performance in court. A vision possibility was stipulated by Avi-Yonah, when he recognizes different ways of observing business individuality, which is why it was decided to use the nomenclatures developed by the author.

Thus, firstly, the representation of legal entities in the Brazilian Labor Court is analyzed, taking as a basis the applicable laws, such as the Consolidation of Labor Laws, the Civil Code and the Civil Procedure Code, in addition to the doctrine and jurisprudence, which substantiate the problem to be developed due to the discussions they often establish on the application of the described regulations.

Then, a study is made on how to understand the company as a legally constituted person. At this moment, it was decided to use the nomenclature corporate forms to develop the ideas that the company can be seen as an aggregate, a fiction or a reality, from which one can discuss the effects of these forms perception in defining the legitimacy of people who speak on their behalf in the course of labor actions.

Finally, a parallel is established between these corporate forms and corporate representation in the Brazilian Labor Court, as a way of developing new arguments against or in favor of the existing limitations of the figures of business representatives and representatives.

Through a theoretical-qualitative research, a bibliographic, normative, doctrinal and jurisprudential review about the representation of legal entities in Labor Justice is sought, analyzed under the scrutiny of the Avi-Yonah doctrine.

\section{The Representation of Legal Entities in Brazilian Labor Justice}

When it comes to the representation of legal entities, one must initially recognize that there is a significant difference between what is represented in material and procedural law.

Under the context of material law, the act of representation is related to the duty of a person to act for another person, who, due to their own limitations, cannot by themselves perform the acts that will be then realized by the representative. It is, therefore, the case of the incapacitated, who need to be represented to exercise the acts of civil life due to their incapacity.

On the other hand, in a procedural relationship, the duty of representation is related to the burden of making claims, in court, on behalf of a third party. In this sense, the representative is not a plaintiff or a defendant, nor does this person seek the satisfaction of their interests but acts in the name and in defense of the rights of the person they represent, given the extraordinary legitimacy that is conferred on them due to the person's limitation (Lima, 2017).

A company, in spite of the discussions about its existence and about its form, which will be analyzed in the following item, needs an individual to act on its behalf, as a way of guaranteeing its claims. In the specific case of Brazilian Labor Justice, it is necessary to make some considerations before it is possible to begin to analyze the issues related to the representation of legal entities. It is important 
to note that the term "legal entity" will be routinely used as a synonym for company or corporation, following Brazil's legal tradition.

First, in labor relations, the legal entity will necessarily be the employing party, since art. $3^{\text {rd }}$ of the Brazilian Consolidação das Leis do Trabalho-CLT (Consolidation of Labor Laws) defines that an employee is an individual who performs work personally (Brazil, 1943), meaning that companies cannot, at least theoretically, be workers, but only employers. The best doctrine identifies this characteristic as the personality of the employment relationship.

Despite the initial provision of art. $2^{\text {nd }}$ of the CLT in the sense that the employer is a company, individual or collective, the first paragraph of this article allows, for the exclusive purpose of recognizing the employment relationship, the assimilation of certain individuals to the figure of the employer, as is the case with self-employed professionals and domestic employers.

Thus, when it comes to legal entities in the Brazilian Labor Court, they are the employers exclusively, whether as the plaintiff or the defendant. So much so that one of the ways to distort the employment relationship is to establish the need for the worker to constitute a company for the provision of services, a practice known as Pejotização. The provision of services through legal entities, in theory, precludes the application of labor rights, which will only be due in case of recognition of the irregularity of the business constitution, given the singular objective of defrauding the employment relationship.

This distinction is important, within a scientific analysis, so that it is not confused with the permissive nature of consumer relations, whose central figures, namely, the consumer and the supplier, can be both individuals and legal entities, under the terms of articles $2^{\text {nd }}$ and $3^{\text {rd }}$ of the Brazilian Consumer Protection Code.

As a result of article 843 of the Consolidation of Labor Laws, in relation to the legal entity employer as a party, the need to be properly identified by means of a natural person is increased, since the said article determines that, in the labor hearings, the parties must be physically present, without making any distinction to the corporate figure (Brazil, 1943).

When analyzing this issue, Lima (2017) argues that, in cases where the legal entity employer puts itself in a hearing through the managing directors or owners, these people should be considered "presenters" (and not representatives), to the extent that the acts they perform do not belong to the partner's own physical person, but to the legal entity itself. Only in the event that a third party is appointed by the partner/administrator will there be representation for the author.

Despite this, a considerable part of the doctrine and jurisprudence, in addition to the legislation itself, refers to this administrator still as a representative. This alone demonstrates the need for the discussion proposed by this article.

This position of the administrator as the figure of the legal person, leaving the debate on the "presentation" or representation for the moment of the discussion of the corporate forms, is established by article 75 of the Brazilian Código de Processo Civil, CPC (Code of Civil Procedure). 
The Brazilian Code of Civil Procedure establishes in the referred article, in its item VIII, that the legal entity will be represented by the person who is highlighted for the purpose by the constitutive acts of the company. If no specific people are designated for this purpose, it will be the directors of the legal entity, thus also understanding its partners and owners or entrepreneurs, to play such role. It is also worth noting that item IX of art. 75 of the Brazilian Code of Civil Procedure establishes that irregular societies and associations and depersonalized or organized entities without legal personality will be represented by the person responsible for the administration of their assets. Finally, item $\mathrm{X}$ of art. 75 of the CPC establishes that foreign legal entities will be represented by the manager, representative or administrator of the unit of the company open or installed in Brazil (Marinoni, Arenhart, \& Mitidiero, 2017).

The CLT and the other norms of labor law and process do not bring their own rules on the natural person to practice, within the Labor Process, the acts of the corporation. Thus, in view of this gap in labor standards, and in view of the compatibility of art. 75 of the CPC, the same rules for the (re)presentation of companies will be used in labor claims, pursuant to art. 769 of CLT and art. 15 of the CPC (Didier Jr., 2018).

It is important to highlight that the understanding of the Brazilian Tribunal Superior do Trabalho-TST (Superior Labor Court) in the sense that it is unnecessary to gather the constitutive documents of the legal entity to prove the people who have legitimacy to act on their behalf. Under the terms of Orientação Jurisprudencial-OJ (Jurisprudential Guideline) No. 255 of the Subsection of Individual Disputes of No. I of the TST, only if the opposing party presents a challenge will it be necessary to present the constitutive documents to confirm the (re)presentation.

As for the economic group (a collective of companies), whose component companies may be jointly and severally liable in labor matters under art. $2^{\text {nd }}$, $\$ 2^{\text {nd }}$, of the CLT, Leite (2017) explains that, previously, the perception of the TST was in the sense that, by guaranteeing the autonomy of companies, each juridical member of the economic group should be represented by one of its partners or legal representatives (article 75 of the $\mathrm{CPC}$ ), who could also indicate representatives for each company.

However, this understanding that was established through the TST Precedent 205 has since then been shifted, which is why it was canceled. Currently, the most recent rulings have admitted that legal entities that are part of an economic group are represented by a single partner/director, who can nominate a representative, so that the representation is made of the entire group. This understanding, which was recognized in the TST Newsletter No. 84, is based, by Miessa et al. (2017), in the "adoption of the active solidarity thesis" for economic groups.

It should be pointed out, however, that the labor procedural rules bring, in some moments, specific modalities of corporate representation, especially for acts performed in audience.

This proves to be very important considering that in the labor procedure there 
is a much higher incidence of acts performed in the audience, which reinforces the recognition that the principle of orality prevails in the Brazilian labor procedure systematic. This is proved by the high incidence of peculiar institutes of the labor procedure that are or must be produced orally, such as the initial petition (art. 840 of the CLT), the challenge (art. 847 of the CLT) and the final allegations (art. 850 of the CLT), which will be practiced, at least in theory, by the representatives of art. 75 of CLT, in the case of a legal entity.

On the other hand, the Brazilian legislator, when establishing the procedural labor rules, seems to have been concerned with possible limitations that could occur due to the requirement of the presence of the partners/administrators in procedural acts practiced in the hearing, which, as seen, is the rule. This could even prove to be an unconstitutional limitation on the fundamental guarantee of access to justice.

For this reason, there are rules that allow legal entities to be represented by third parties at a hearing.

The first paragraph of article 843 of the CLT establishes that the employer can be replaced by a manager or an agent who has knowledge of the facts, and their acts oblige the legal entity. This person is named preposto, or prepost.

The appointment of the manager as a representative of the legal entity is justified by the fact that they are a professional invested with a management function, which is why they would almost always have knowledge of the facts and business procedures well enough to exercise the activity of representation.

The preposto, however, is a special person, whose role of representation is voluntarily granted by the employer to perform acts and make statements on their behalf at hearings in the course of a process. It is appropriate to emphasize that the representation by the prepost is limited to the acts performed in the hearing, not reaching the other procedural acts by means of a petition, including appeals (Cairo Júnior, 2017).

In general, the powers of this kind of representative are indicated by means of a document called the Letter of Preposition. It is a practice of the Brazilian Labor Justice that part of the doctrine deems necessary, as stated by Schiavi (2016), but that a considerable part of the doctrine (Cairo Júnior, 2017), in addition to the jurisprudence, understands optional, due to the lack of a legal norm that addresses this need.

In any case, in the event that the magistrate understands that the Letter of Preposition is necessary, he must grant the party reasonable time to regularize his representation, under the terms of art. 76 of the CPC, under penalty of, if any sanctioning decision is taken due to such fact, fall into the forbidden practice of surprise decision, prohibited by art. 10 of the CPC (Brazil, 2015). In theory, the deadline to be granted has already been defined by the TST through Precedent 456 as being 05 (five) days.

Perhaps the most significant legal stir with regard to the representative in the Labor Court is the need or not for the person indicated to be employed by the 
represented company.

Despite the absence of a rule that foresees such a need, the TST initially established, through the Jurisprudential Guideline No. 99 of SBDI-1, dated 1997, the understanding that there would be a need for the employer's representative to be necessarily an employee, except in the case of a domestic employer.

With the establishment of this understanding, it was the duty of the prepost to present, on the day of the inaugural hearing, their labor contract, so that the person's condition of employee could be verified. If it were not presented, the party should be allowed a period to do so, under the terms of art. 13 of the CPC in force at the time (Schiavi, 2017).

The first discussion on this requirement to take a greater proportion was the question exposed by Leite (2017), who understood that, with the expansion of the jurisdiction of the Brazilian Labor Court that occurred through Constitutional Amendment No. 45/2004, including labor relations as a matter to be judged by the labor judiciary, the position would have to be reviewed.

The author explained that, while the Brazilian Labor Court had only been competent to judge employment relationships, the requirement of OJ $n^{\circ} 99$ of SBDI-1 of TST would be justified. However, with the insertion of the competence to judge issues related to general labor relations and not only employment as previously, which occurred due to the modification of art. 114, I, of the Brazilian Constitution, the rules of representation to be followed are not provided for in the CLT, but those of the CPC, in articles 75 and 76. Thus, the service taker, unlike the employer, should use the rules of (re)presentation, not being entitled to the benefit of the prepost. Schiavi (2017), on the other hand, understands that service providers can appoint third parties who do not provide services to them as agents.

In 2005, the OJ $\mathrm{n}^{\circ} 99$ of the SBDI-1 of the TST was converted into Precedent (in Brazil, Súmula) 377 of the TST, which made no mention of labor relations.

Then, with the advent of Complementary Law 123/2006, which in its art. 54 allows small employers and microenterprises to be represented by third parties who are not employees, the Precedent has been amended to include such exceptions.

Despite this, the specialized doctrine continued to question this need. Schiavi (2017) presents as reasons for the unnecessity of the employment relationship for the prepost: the lack of legal provision, the limitation to access to the employer's justice, the possibility that third parties knew as well about the facts as an employee, and the employer's exclusive risk of appointing a person who does not know the facts to speak on their behalf. The author also listed authors who joined this philosophical line, such as José Augusto Rodrigues Pinto, Amauri Mascaro Nascimento and Melchíades Rodrigues Martins, in addition to exposing statements from several Brazilian Regional Labor Courts in this regard.

On the other hand, Schiavi (2017) is in agreement with the TST in the sense that there is a need for the representative to be an employer, except in the hypothesis of Precedent 377 of the TST, for reasons of being a need that the person to 
know the facts, to have the principle of orality in the work process, to seek the real truth, to avoid the professional representatives and to moralize the work process. He listed as authors who also followed this understanding Francisco Antonio de Oliveira and Jorge Luiz Souto Maior, and other statements of Regional Courts.

The matter remained in accordance with Precedent 377 until the Labor Reform that took place through Law No. 13,467/2017, which added item 3 of article 843 of the CLT, which establishes the need for the employee to be employed by the company, contrary to the understanding of the TST.

Despite the new legal provision, the TST has not yet canceled the said Precedent, despite admitting the new wording of the normative text. The need for knowledge of the facts remains and can be used for the declaration of irregularity of representation if this requirement is not met.

Finally, it is important to note that the lawyer cannot cumulate the function of prepost and attorney, due to the prohibition of the Brazilian Statute of Advocacy. If the lawyer attends the hearing without the party presenter or representative, whether partner/entrepreneur, manager or agent, the effects of default will occur, in the terms of Precedent 122 (Cairo Júnior, 2017). However, the documents presented by the lawyer, in the best doctrine understanding, should be attached to the case file (Schiavi, 2016).

However, there seems to be no impediment, after the insertion of paragraph 3 of article 843 of the CLT, from the signing of a preposition letter in the name of the lawyer, who will not act as a lawyer, but as a representative using the jus postulandi of the litigant of art. 791 of the CLT.

Having made the considerations on the model of representation of companies in the Brazilian Labor Courts, the discussion on the nature of the legal entity should then be presented, so that the analysis of the adopted nature view regarding representation is later possible.

\section{The Corporate Forms as Real or Fictional Entities}

The analysis that is sought to be developed in this paper starts from a discussion that has long been made about the perception of legal entities by the legal systems.

In fact, this discussion is not limited to the analysis of companies under Brazilian law but ends up giving rise to research in different legal systems, in addition to being a topic that can even be raised at an international level.

This article will focus on Reuven Avi-Yonah's doctrine on the issue, but not without first acknowledging that the study carried out may come from several other authors, who similarly may have approached the topic, probably without reaching a definitive conclusion. For this reason, the option of using the Reuven Avi-Yonah doctrine has as its primary objective scientific constancy, especially for nomenclature purposes.

In his research, Avi-Yonah (2005) describes that since the conception of the idea of a legal person in Rome, whenever there is a change in the role of compa- 
nies, debates about their nature arise that, in a cyclical way, seek to establish themselves as the correct company theory.

The author points out three theories that seek this identity, which are the aggregate entity theory, artificial entity theory and real entity theory.

In order to analyze the historical changes, it is appropriate to point out the way in which Avi-Yonah (2005) defines the three theories about the company's perception vis-à-vis the partners.

First, the theory of the aggregate entity, or perhaps more correct, the theory of aggregation, due to the limited perception of the company as an entity in this theory, is the view of the company as a conglomerate of people and things that do not have a unit. In this view, there does not seem to be, in fact, a business personality, but rather a group of people who act collectively for themselves, which is why they must also be collectively considered.

Second, the theory of the artificial entity means the perception of the company as a fictional being that is idealized by a superior permissive, coming from the one who, at that moment, had the power to recognize this artificiality, such as an emperor, a parliament or the State.

Finally, the theory of the real entity views the company as a separate entity from its members. In this perception, from its conception, the company's operating body is obviously represented by its partners, but who act in the interest of the business entity, and which can be changed without affecting the existence of the company itself, since this is different from them.

After a brief study of the theories' concepts about the corporate form, it is possible to analyze the transformations so that one can see how these theories behave.

Initially, the author states that this view of the company as a distinct entity from its partners is essentially Western, starting with Roman Law in 200 BC, expanded in the Middle Ages in both canon and civil law and adopted by non-Western systems, as in Law Islamic, and common law, as in Anglo-Saxon Law (Avi-Yonah, 2005).

Despite the initial difficulty of making such a historical analysis, given the ambiguity of the ancient texts, Avi-Yonah (2005) says that it is possible to recognize the three theories from the moment when the existence of the company was proposed as a person. This, according to the author, was the first transformation of the company vision, which was then followed by three more.

In this first transformation of the concept of company, there was, in Romanesque law, the recognition of corporations as legal persons, with legal attributes, such as the ability to own property, to file lawsuits and answer for their actions.

In this sense, it is possible to observe the theory of the aggregate entity in texts by the classical jurist Paul, who develop that, as the members of a corporation cannot have a single animus, they cannot really own anything, but they can act for the collective; the artificial entity theory in Gaius texts, which emphasized that, without the imperial authorization for the creation of corporations, they 
could not have legal personality, own property or have an agent who can act on their behalf., and the entity theory in Ulpian, which sees the company as separate not only from the individual members, but also from the number of individuals together, since when the company establishes a representative (for example, a lawyer), they act in favor of the corporation itself and not of a group.

In the Middle Ages, the three theories are still visible, as in texts by Franciscus Accursius, who around the year 1250, dealt with both the theory of the artificial entity, recognizing that the power of the company is that granted by the emperor, as well as the theory of aggregation, when saying that the agent who acts on behalf of the company, which he calls the Receiver, actually acts on behalf of a collective of people, and the theory of the real entity, when he understands that even with the change of partners, the company remains intact.

The second transformation in history refers to the shift from the creation of businesses primarily nonprofit to businesses primarily for profit, which occurred in the eighteenth century.

Here, Avi-Yonah (2005) points out that, with the change in the view of private corporations as mainly philanthropic or indirectly supporting entities, such as schools and hospitals, for entities that seek profits, the previous debate about the nature of legal entities resurfaces.

The author then identifies, based on the debate created with this transformation, the three theories. By the way, he manages to identify them from the positions of the famous American jurist and main founder of American constitutional law and consolidator of the judicial review John Marshall in three different manifestations, in three different decades, and which clearly represent the evolution of the magistrate's vision about corporations.

In the first situation, in the case of Bank of America v. Deveaux, Marshall was urged to speak out about "the individual character of the members is so completely lost in that of the corporation, that the court cannot notice it" and the contrary view that "a corporation is made up of individuals", that is, between a view of the company as an entity, artificial or real, and a view of an aggregation. In this case, the judge would consider whether the fact that a specific branch of the Bank of the United States located in the city of Savannah, in the state of Georgia, should be considered an entity of that state, being subject to the jurisdiction of that state, or if the fact of that state branch is made up of people who are citizens of Pennsylvania, which would make the conflict with the state of Georgia under federal jurisdiction. Marshall's decision opted for the aggregation theory, the company not being its own entity, but people in a collective. If these people, in this case, are citizens of the state of Pennsylvania, and a dispute is filed against the state of Georgia, it would then address a conflict of citizens of different states, which would attract federal jurisdiction.

In the second case ten years later, Trustees of Dartmouth College v. Woodward, the state of New Hampshire attempted to change the charter of Dartmouth College by transferring the appointment of trustees to the state, effective- 
ly taking control of it. The trustees objected, arguing that the letter constituted a contract, and the amendment violated the US Constitution's contract clauses.

In this instance, Marshall decided that, although the creation of the corporation is permitted by the State, the State cannot consider it an extension of itself, and that, even if the corporation is an artificial, invisible, intangible and existing only in contemplation of the law, the funds for the Faculty came from private sources and its educational character also did not make it public, it only has the properties that the Charter of its creation gives it. Thus, in this case, Marshall was in favor of the theory of the fictional entity.

The third time Marshal was asked to speak out about the nature of the companies, six years after the second case, was in Bank of the United States v. Dandridge, in which Dandridge, who had been a bank teller, executed an obligation that, in response, was challenged on the grounds that the obligation had never been approved by the Board of Directors, as required by the Letter of Incorporation. It was questioned whether the level of evidence/proof required from companies was higher than that required from individuals, since companies are unable to act if not in writing. While the Court held that no distinction should be made, Marshall understood that the company is an entire impersonal entity, distinct from the individuals that compose it, and must be endowed with its own mode of action, which always distinguishes its transactions from the transactions of its members.

Thus, in this third moment, Marshall's view was more consistent with the theory of the company's real entity as distinct from its members, individually or collectively.

Avi-Yonah (2005) explains that Marshall's change of vision was circumstantial. In the first case, he wanted to guarantee jurisdictional diversity to protect a federal entity, which would only be possible by seeing the company as an aggregate of natural persons. In the second case, Marshall emphasized the role of the state in the creation of the corporation, while setting clear limits on its ability to regulate corporations, as a way of preventing the state from taking on private business in the face of the proliferation of companies, especially companies for profit. This second case seemed to pave the way in the third, given that it reinforced the company's recognition as its own entity.

The author also argued that the understanding that took force in the end was that of the theory of the real entity because limited liability weakened the aggregate view and the general incorporation weakened the artificial view. In addition, the American Supreme Court, in future decisions, was opposed to Marshall's two initial understandings.

The third transformation came from the shift from small, privately held companies to large publicly traded companies, which again required a reexamination of the corporate form, and again the three theories of the corporation appeared.

In this sense, in addition to other cases presented, Avi-Yonah (2005) points out the Hale v. Henkel, tried by the American Supreme Court in 1906, in which 
it was discussed, given the size of the company and its publicly held company, whether it would have access to the fourth and fifth amendments to the American Constitution.

The Fourth Amendment was invoked as a way to protect the company from irrational search and seizure procedures. In the first moment of the debate, the judges presented an analysis that reinforced the theory of the artificial entity, when saying that the company receives certain privileges and special franchises by the State that it keeps subject to the laws and the limitations of its statute. The company "cannot make any contract not authorized by your letter. Their rights to act as a corporation are only preserved as long as they obey the laws of their creation". Thus, while a natural person may legally refuse to answer incriminating questions, "it does not follow that a company, invested with special privileges and franchises, can refuse to show its hand when accused of abusing such privileges".

However, the author then states that, in order to close its decision regarding the use of the Fourth Amendment, the Court turned to the theory of aggregation, saying that, as a collective of people, the company would have the benefit of indirect protection, since the bodies of the people who compose it are in fact protected.

Finally, as for the Fifth Amendment, which deals with the right of no self-incrimination by the accused, the Court adopted a position aligned with the theory of the real entity, when removing the company from its partners, which is why, given its peculiar nature, there is no way to produce oral evidence.

The fourth and last transformation described by the author deals with the change from national corporations to multinational companies. This transformation, according to the author, started in the 1950s and continues today, which is why it is difficult to identify the final answer.

Multinationals, according to the author, have existed since the seventeenth century. However, the recent change is that, until the 1950s, these companies were still centrally based in one country, adjusting to it, with shareholders and other sources of capital, management, most production facilities and most markets were in the country.

However, as of the 1990s, a process of changing this issue can be seen, since new forms of business, new products and greater ease in transport make the operation of multinationals globalized.

In this sense, the sources of capital are in many countries, the shares are traded on various stock exchanges and the lines of financing are equally diversified. Research and development and production facilities are also spread across the world, as are markets. The only thing that normally links a modern multinational to its home country is the location of management.

Thus, the debate on the nature of companies reopens. The relations of multinationals with their respective states of origin change, and this makes it necessary to see how corporate identity is maintained. 
Avi-Yonah (2005) argues that this change makes it particularly difficult to maintain the theory of the fictional entity.

It is important to recognize that Avi-Yonah points out that, despite the cyclical way in which theories appear in history, the theory of the real entity excels in the four transformations, and that this trend seems to be followed in today's legal systems.

In Brazil, despite the discussion that still exists, this tendency is also followed, since the civilist doctrine defends an approximation of majority understanding in the sense that the theory adopted by the Brazilian legislation is that of the company as a real entity, although with some fictional aspects.

They argue that this is the vision of the Civil Code of 2002 consecrated authors such as Tartuce (2019), Donizetti and Quintella (2018) and Gonçalves (2018).

In the Civil Code of 2002, the doctrine has pointed out Article 45 of the Brazilian Civil Code as an example of the provision of the theory of the real entity. On the other hand, as an argument in favor of a possible adoption of the theory of the fictional entity is Article 50 of the Civil Code. This in itself demonstrates that the analysis of the legal text theoretically representative of the legislator's will does not solve the impasse presented here.

In addition, from the two articles mentioned, it can be said that Brazil has apparently moved away from the concept of aggregation theory.

Even in the study of corporate types, there may be doubts about which theory to be adopted. In this sense, corporate societies seem to have a much closer aspect to being a real entity, while civil societies are more like fictional entities.

This is because civil/simple societies are linked by a much stronger personality bond than business societies, which are much more focused on financial receipt through specific business activities.

In this sense, civil societies have a more personal relationship between partners, who represent them much more than the partners of business companies. This means that the identity of the people who make up simple companies has an importance that the identity of the partners of business companies does not have.

The importance of identity reflects the two theories of the company as an entity because in both cases the existence of a distinct legal personality is recognized. However, in the case of civil societies, this identity appears as a protective collectivizer of the law, who keeps the partners as central figures, which translates into the theory of the fictional entity. In the case of corporate companies, the creation of the corporate body separates from the partners the figure of the legal person, which exists as an independent third party, no matter who its partners are, or even if these are maintained or modified. This demonstrates the approximation with the theory of the real entity.

This discussion, by itself, would be quite complex and full of contradictory arguments that could lead to conflicting perceptions for which theory would be 
applied for each type of company. The truth seems to be that there is not just one theory, but societal types that have characteristics of both theories.

This debate would be applicable in another singularized study, which is not intended here. Right now, the duty is to analyze the issue of the theories of the company in representation in the Brazilian Labor Court, which will be done next. What has been tried to show so far has been how each company theory behaves, and how the theme addressed is complex and does not seem to have, in any sphere or approach, a definitive answer.

\section{Business Representation in the Brazilian Labor Justice from the Corporate Forms Conceptions}

The historical considerations made by Reuven Avi-Yonah on corporate forms, that is, that companies can be a collection of people, a fictional entity or a real entity, show the tendency for theories about the business nature to appear in a cyclical way, and this reality is no different today.

As an example, the question of the nomenclature of the partner's performance as the company itself demonstrates, albeit superficially, the continued need for this type of debate, in addition to revealing that there is still no confirmation of any of the theories.

By recognizing the need to adopt the terminology "present" in place of the verb represent, it is possible to identify a tendency of the doctrine to opt for the use of the theory of the fictional entity for questions regarding representation, despite the superficially peaceful positioning that the Brazilian Civil Code adopted the theory of the real entity, although mitigated.

The question of the use of the term "presentation", which, by the way, did not even exist in Portuguese dictionaries before this debate, demonstrates a certain belief that there is no physical personality of the company other than that of the natural person who stands in his place.

It is not a third party that represents it, but the company itself, which is actually a theoretical permissive that, when it needs to be put into physical form, it is actually the partner who acts. In this conception, there is no real identity of the company, but an appearance, a fiction that covers the corporate group.

Despite what was previously demonstrated in the sense that Brazilian doctrine has been pointing to the theory of the real entity as the one adopted by the Civil Code, the use of the term "presentation" has been widespread, which is why, even, the word has come to be recognized by the Portuguese Language Orthographic Vocabulary.

The partner, when "presenting it", is the company. They are inseparable, and the legal permissive aspect of the corporate constitution reflects only on the creation of a fiction that will cover the partners when they are in the exercise of the business activity, but that still will only be considered those natural persons that actually exist. To the company there is only the right to fictionally exist through the law. 
On the other hand, when the term representation is used, there is the idea of two people: the legal entity, separated from its partners, and the natural or physical person who represents it, legitimized by the status of partner or owner. That is, the use of this terminology demonstrates a conception of the company as a real person.

This debate, by itself, already demonstrates that discussions about (re)presentation can be made from the views of the nature of legal entities. At this moment, it is sought to make this analysis in order to understand the best way to verify the theory incident in the representation of the company in the Brazilian Labor Court, which is more complex than in the case of the use of the term presentation.

In several aspects, the issue of representation in the Brazilian Labor Court seems to tend to a view closer to that of the legal person as a fictional entity.

An example of this vision is the new trend, as mentioned earlier, that economic groups can be represented by only one director. In this conception, it is obvious that legal entities that make up an economic group do not appear to be real entities, but fictions, given the fact that the prevailing understanding does not retain an idea of individuality to be preserved, but a cluster of interests and protections that, at the moment of representation, converge, which is why they can be moved by a single representative.

The previous jurisprudential position, represented by the TST Precedent 205, identified a view of the legal entity as a real entity. Leite (2017) reinforces this concept by establishing that this understanding existed since each legal entity in the economic group "would retain its administrative, legal and financial autonomy".

If the company is seen from a fictional point of view, the people who compose it, according to the constitutive document, are actually the entity itself. In this sense, there are no people related to the demand other than the plaintiff and the partners against whom he is sued, involved in a series of fictitious aspects that make up the idea of a company.

In this view of the legal entity as a fictitious entity, when there is a labor claim against employer companies, the claim is processed inseparably against the partners' natural people, who must necessarily appear in court to respond to the action.

This does not mean to say, it is important to emphasize, that the assets of the partners will account for the eventual condemnation made by the court, inasmuch as there is, still in the fictional view, social capital assigned to the legal entity, which must initially answer for its debts. Obligations are intended for fiction involving the owners.

What is observed, however, is that, in fact, the conviction will affect the partners, necessarily, since the company's capital is truly the composition of the portions of the assets of the partners assigned to the Legal Entity.

The effects of this conception, in the sense of representing the company in the Labor Court, can be identified especially by the need for the individual representing 
the company to be employed by the company. This is because, considering that the idea of the legal entity is essentially fictitious, representatives and representatives are persons appointed by the partners, according to their own choice, based on their own criteria.

In this sense, there is no need to talk about exclusive "presentation": to call the legal entity to the file is to call the natural persons of its partners. Those partners who present in audience do the work of representing the others. This same representation also occurs in the manager's prominence for the manifestation in court.

In the situation of the partners being represented by a prepost, in the same idea, it is a case of the election of a third party to put themselves in the situation of the partners themselves.

In the exercise of the capacity to stand in court, inseparable from the postulatory capacity granted to the litigants due to the principle of jus postulandi of the parties in the Brazilian Labor Court of article 791 of the CLT (Brazil, 1943), it would be justifiable to demand from the representative only the knowledge of the facts, for that they could be heard by the court, clarifying the controversial points of the demand and making it possible, through the deposition as part, the final decision of the magistrate.

It can also corroborate with the company's view as a fictional entity that the prepost does not need a letter of preposition. This positioning removes the similarity between the prepost and the representant's figure, who is a person who represents another, and creates the appearance of a person who presents themselves in the name of a fictional being, whose presentation, because it needs a natural person, can be transmitted to someone by the faculty granted by law, regardless of willingness to.

Despite these characteristics that corroborate with a fictional perception of the company, there are points that must be raised that also allow to glimpse a vision of the company as a real entity at this point.

When there is a conviction for bad litigation or procedural damage of the representant, who is responsible for the payment? The party itself or the attorney? In this sense, is the representative who practices litigation in bad faith or causes procedural damage condemned in his own name, or is the company that is convicted?

When the partner, manager or representative acts in a hearing, they do not act in their own name, but in the name of the company. This is a view of the company as a real entity, since naturally the responsibility for any harmful acts practiced by the representative will be imputed to the legal entity, which will bear the indemnity through its own assets.

In this sense, the existence of the company is recognized, distinct from its partners, who act physically as a legal entity, and not themselves as individuals.

If the partner, manager or agent acts in a reckless manner, causes hindrances to the smooth running of the process or in any way incurs an act that generates 
the duty to indemnify the other party for procedural damage, the fine applied will not be to the natural person, but to the part itself.

This will also be the case if the partner, manager or representative makes a confession: there will be no confession by the individual, but a confession by the legal entity, considering that it presented the statements.

In these cases, it demonstrates much more how the Consolidation of Labor Laws and the Code of Civil Procedure see the individual who speaks on behalf of the company as a representative. It would even be possible to establish, in this topic, an approximation of the concept of attorney.

In fact, the feeling created by the laws is that there is a separation between the company and the natural person who speaks on their behalf. In the exercise of representation, it is not necessary to speak of a physical person invested with a fiction, but of a person who speaks on behalf of another, that is, two distinct people.

Were it not so, if it were interpreted by the understanding of a fiction, in the event that a physical act taken by the representative is reprehensible or generates a duty to indemnify, there would be no reason to determine the conviction of the legal entity.

Thus, an apparent approximation is created, in this sense, with the theory of the real entity, since the company is seen as a person in itself, separated from its partners after its constitution.

This only reinforces what Reuven Avi-Yonah described in the sense that, after the various transformations through which companies went through, the theory of the real entity stood out, despite the difficulty of clearly and definitively establishing this preference.

In the debate on representation in the Brazilian Labor Court it does not seem to be different. Despite the various points that favor the perception of the use of the theory of the company as a fiction, the analysis leads to believe that the feeling of doctrine, legislation and jurisprudence still reflects a vision of the company as a real entity.

In any case, it is imperative to recognize that there are several nuances to be observed, and that even subjective points such as the researcher's opinion can influence the response to the problem developed. Thus, more thorough research would be necessary, in order to proceed with the creation of an answer as complex as the question itself.

\section{Conclusion}

Based on the concepts developed by the doctrine of business and civil law, in particular by analyzing the writings of Reuven Avi-Yonah, it was sought to develop the perception of companies applied to the representation of the legal person in the Labor Court: as a real entity or a fictional being. The objective of the research is to promote an analysis on how the perception of corporate forms has influenced business representation in the Brazilian Labor Justice. 
Representation in the Brazilian Labor Court is mainly based on the format of article 75 of the Brazilian Code of Civil Procedure, with the company representative being its partner or owner, or through the permissive provision of article 843 of the Consolidation of Labor Laws, through the manager or the representative.

Regarding theories about the nature of the company, one can highlight the theory of the fictional being, in the idea that the company is a fiction created by a higher power (nowadays, the Law and the State) that is established around the partners as a safeguarding of these and their assets when operating in the market, and the theory of the real entity, in which, after the company's constitution, the figure of the legal person and the natural persons that compose it is separated.

Based on the dialogue that was sought to establish, it was possible to register that, in the representation issue, there are points that corroborate for the application of both theories, but there is a certain apparent prominence for the application of the company's theory as a real entity.

Undeniably, more in-depth studies on representation in the Brazilian Labor Court and its perception of the entrepreneurial nature need to be carried out. Given the complexity of the topic, it is essential that new debates are held so that it is possible to establish, with greater security, the model that is proposed.

\section{Conflicts of Interest}

The author declares no conflicts of interest regarding the publication of this paper.

\section{References}

Avi-Yonah, R. S. (2005). The Cyclical Transformations of the Corporate Form: A Historical Perspective on Corporate Social Responsibility. Delaware Journal of Corporate Law, 30, 767-818. https://doi.org/10.2139/ssrn.672601

Brazil (1943). Decreto-Lei 5.452, de $1^{\circ}$ de maio de 1943. Rio de Janeiro, RJ: Consolidação das Leis do Trabalho.

Brazil (2015). Lei 13.467, de 13 de jul. de 2017. Brasília, DF: Lei da Reforma Trabalhista.

Cairo Júnior, J. (2017). Curso de Direito Processual do Trabalho (10th ed.). Salvador: Jus Podivm.

Didier Jr., F. (2018). Curso de Direito Processual Civil, Volume I: Introdução ao Direito Processual Civil, Parte Geral e Processo de Conhecimento (20th ed.). Salvador: Jus Podivm.

Donizetti, E., \& Quintella, F. (2018). Curso Didático de Direito Civil (7th ed. ver. e atual). Salvador: Atlas.

Gonçalves, C. R. (2018). Direito Civil brasileiro, Volume I: Parte Geral (16th ed.). São Paulo: Saraiva Educação.

Leite, C. H. B. (2017). Curso de Direito Processual do Trabalho (15th ed.). São Paulo: Saraiva.

Lima, L. T. B. (2017). Lições de Direito Processual do Trabalho: Teoria e Prática (4th ed. rev. amp). São Paulo: LTr.

Marinoni, L. G., Arenhart, S. C., \& Mitidiero, D. (2017). Novo Código de Processo Civil 
Comentado (3th ed. rev., atual. e ampl.). São Paulo: Revista dos Tribunais.

Miessa, É. (Org.), Correia, H. (Org.), Miziara, R., \& Braga, R. W. (2017). Informativos do TST Comentados e Organizados por Assunto (2nd ed. rev. e ampl.). Salvador: Juspodivm.

Schiavi, M. (2016). Manual de Direito Processual do Trabalho (10th ed.). São Paulo: LTr.

Schiavi, M. (2017). A Reforma Trabalhista e o Processo do Trabalho. São Paulo: LTr.

Tartuce, F. (2019). Direito Civil: Lei de Introdução e Parte Geral (15th ed.). Rio de Janeiro: Forense. 